\title{
Increasing nitrogen use efficiency with lower nitrogen application frequencies using zeolite in rice paddy fields**
}

\author{
Qi Wu ${ }^{1}$, Taotao Chen ${ }^{1}$, Daocai Chi ${ }^{1}$, Guimin $\mathrm{Xia}^{1}{ }^{*}$, Yidi Sun ${ }^{1}$, and Yonghua Song ${ }^{2}$ \\ ${ }^{1}$ College of Water Resource, Shenyang Agricultural University, Shenyang, Liaoning 110866, P.R. China \\ ${ }^{2}$ Water Conservancy Bureau of Donggang, Dandong, Liaoning 118000, P.R. China
}

Received July 21, 2018; accepted December 22, 2018

\begin{abstract}
Zeolite can effectively regulate the nutrient status in the root zone of crops, thereby increasing nitrogen utilization. However, there has been relatively little research conducted concerning a possible reduction in the frequency of nitrogen application due to the sustained-release properties of zeolite. In this study, $157.5 \mathrm{~kg} \mathrm{ha}^{-1}$ nitrogen in the form of urea fertilizer was applied at the same rate, either as a one-time application or as a 3-way split application with and without $10 \mathrm{t} \mathrm{ha}^{-1}$ zeolite. The effects on rice yield, nitrogen uptake, root morphology and soil properties were evaluated in 2014 and 2015. Results showed that zeolite could enhance the biomass, leaf area index and nitrogen uptake. A higher rice grain yield and nitrogen uptake following soil treatment with zeolite could be attributed to a higher soil cation exchange capacity as well as nitrogen and potassium availability in the soil especially during the vegetative period of the rice plant. The addition of nitrogen to the soil as a one-time application or 3-way split application with $10 \mathrm{tha}^{-1}$ zeolite significantly increased rice grain yield by 8.5 or $10.7 \%$ compared with nitrogen as a one-time application without zeolite. Zeolite addition greatly improved the development of root morphology and activity compared with treatments without zeolite, which contributed to additional plant growth. The addition of nitrogen to the soil with $10 \mathrm{t} \mathrm{ha}^{-1}$ zeolite as a one-time application that can significantly increase nutrient retention is recommended to improve rice grain yield and decrease nitrogen application frequencies in order to lower both labour forces and energy requirements.

Keywords: available nitrogen, nitrogen uptake, root system, labour force
\end{abstract}

\section{INTRODUCTION}

Rice has become the most important food crop in Asia because it constitutes approximately $32 \%$ of food calorie intake (Belder et al., 2004). Rice is also a daily source of

*Corresponding author e-mail: daocaichi@vip.sina.com vichine0701@gmail.com

**This work was supported by the National Key R\&D Program of China under Grant 2018YFD0300300 (2018-2020); the National Science Foundation of China under Grant 51679142 \& 51709173 (2016-2019, 2017-2019). nutrition for $60 \%$ of the population of China, the people of that country will require $0.64-0.72$ billion $t$ of rice when the population reaches 1.6 billion, and this is expected to occur in 2030 (Liu and Zhang, 2005; Bi et al., 2009). Reductions in fertilizer use may threaten the production of rice. Therefore, novel or at the very least, reasonable nitrogen $(\mathrm{N})$ management strategies must be explored in order to enhance $\mathrm{N}$ use efficiency (NUE) and rice productivity.

In paddy soil, $\mathrm{N}$ is the most important and widely used fertilizer nutrient, it plays an essential part in developing yield capacity and maintaining photosynthetic activity during the grain filling stage (Wienhold et al., 1995). Hence, management strategies for $\mathrm{N}$ are critical for enhancing NUE and rice grain yield (Sandhu et al., 2012). Ideally, $\mathrm{N}$ management strategies should apply optimum rates and frequencies, which match crop demand (Belder et al., 2004). Appropriate nitrogen management, where the right amounts of nitrogen are applied and best practices are implemented to ensure higher efficiency use, may enhance the availability of soil $\mathrm{N}$ and maintain strong root activity in order to allow the rice plants to increase nitrogen accumulation. However, the improper use of $\mathrm{N}$ has resulted in environmental concerns, especially in developing countries (Barea, 2015). $\mathrm{NO}_{3}-\mathrm{N}$ present in the soil may be susceptible to leaching and hence contaminate the surface soil and groundwater (Ippolito et al., 2011). At a range of 0.2 to $0.5 \mathrm{mg} \mathrm{L}^{-1} \mathrm{NH}_{4}-\mathrm{N}$ concentrations could be fatal to fish and aquatic animals (Weatherley and Miladinovic, 2004). Therefore, a reasonable fertilization regime would not only benefit rice growth, but also greatly reduce the ecological load on farmland.

(C) 2019 Institute of Agrophysics, Polish Academy of Sciences 
Zeolites (Z) are crystalline, hydrated aluminosilicates that have three-dimensional crystal structures (Rehakova et al., 2004; Gholamhoseini et al., 2013). As a non-metallic mineral resource, $\mathrm{Z}$ has been investigated for the purpose of decreasing $\mathrm{N}$ leaching and enhancing soil fertility due to its considerable cation exchange capacity (CEC) and ion adsorbing capacity (Sepaskhah and Yousefi, 2007). $\mathrm{NH}_{4}-\mathrm{N}$ in the pores of $\mathrm{Z}$ crystals could be released slowly for continuous uptake by plants and also decrease nitrification (Sepaskhah and Barzegar, 2010). Researchers have determined the effects of combining chemical fertilizers with $\mathrm{Z}$ and found that $Z$ addition to soil could significantly decrease phosphorus (P) and nitrate leaching (Gholamhoseini et al., 2012). Mixing $N$ with $Z$ significantly increased the rice grain yield due to enhanced $\mathrm{N}$ retention in surface soil (Sepaskhah and Barzegar, 2010; Kavoosi, 2007). However, there was a lack of information available concerning research into decreasing $\mathrm{N}$ application frequencies using the $\mathrm{Z}$ amendment while maintaining higher rice grain yield and $\mathrm{N}$ use efficiency.

Therefore, the objectives of the experiment were to investigate the effects of different $\mathrm{N}$ application frequencies with $\mathrm{Z}$ on rice grain yield, root morphology, CEC, $\mathrm{N}$ uptake, available $\mathrm{N}$ and $\mathrm{K}$ during two growth seasons of 2014 and 2015 in the northeast coastal region of China. Z was only applied in 2014 and no additional $\mathrm{Z}$ was applied in 2015 .

\section{MATERIALS AND METHODS}

The experiment was conducted from May 2014 to October 2015 at Donggang experimental irrigation station (39 $52^{\prime} 48^{\prime \prime} \mathrm{N}$ latitude, $123^{\circ} 34^{\prime} 48^{\prime \prime}$ E longitude and altitudes of $8.1 \mathrm{~m}$ above mean sea level). The area belongs to the continental moist monsoon climatic region of the temperate zone. It is affected by the Yellow Sea and is characterized by a maritime climate. Its average annual air temperature is $8.4^{\circ} \mathrm{C}$. The yearly average precipitation which is mainly concentrated in the summer months is $967 \mathrm{~mm}$. The physical and chemical properties of the soil used in the two-year experiment are shown in Table 1 with reference to our previous research (Chen et al., 2014; Wu et al., 2016a). According to Table 1, the soil texture was a silty clay loam.

The field experiment had a completely random design with 3 replications. There were 4 treatments in this experiment: urea was used as basal fertilization once $\left(\mathrm{N}_{1} \mathrm{Z}_{0}\right)$; urea was used as basal fertilization once with $\mathrm{Z}\left(\mathrm{N}_{1} \mathrm{Z}_{10}\right)$; urea was used as third-split fertilization according to the traditional fertilization method below $\left(\mathrm{N}_{3} \mathrm{Z}_{0}\right)$; urea was used as third-split fertilization with $\mathrm{Z}\left(\mathrm{N}_{3} \mathrm{Z}_{10}\right)$. $\mathrm{Z}$ application rates of $10 \mathrm{t} \mathrm{ha}^{-1}$ could significantly increase rice grain yield in this region under traditional $\mathrm{N}$ regimes (Chen et al., 2014; Wu et al., 2016a). Therefore, $\mathrm{Z}$ was applied at an application rate of $10 \mathrm{tha}^{-1}\left(Z_{10}\right)$ for all 4 treatments.
Table 1. Physical and chemical properties of experimental soil

\begin{tabular}{lc}
\hline Soil properties & Content \\
\hline Sand (\%) & 11.4 \\
Silt (\%) & 66.7 \\
Clay (\%) & 21.9 \\
$\mathrm{pH}$ & 6.61 \\
Bulk density $\left(\mathrm{g} \mathrm{cm}^{-3}\right)$ & 1.412 \\
Available P $\left(\mathrm{mg} \mathrm{kg}^{-1}\right)$ & 32.33 \\
Available K $\left(\mathrm{mg} \mathrm{kg}^{-1}\right)$ & 56.56 \\
Alkali-hydrolysable N $\left(\mathrm{mg} \mathrm{kg}^{-1}\right)$ & 36.55 \\
Total N $\left(\mathrm{g} \mathrm{kg}^{-1}\right)$ & 0.677 \\
Organic matter $\left(\mathrm{g} \mathrm{kg}^{-1}\right)$ & 9.02 \\
\hline
\end{tabular}

The natural $\mathrm{Z}$ used in this study originated from Liaoning province, China. $\mathrm{Z}$ had the following chemical composition (in \%): $\mathrm{SiO}_{2}=65.56, \mathrm{Al}_{2} \mathrm{O}_{3}=10.62, \mathrm{Na}_{2} \mathrm{O}=0.39$, $\mathrm{K}_{2} \mathrm{O}=2.87, \mathrm{CaO}=2.59, \mathrm{Fe}_{2} \mathrm{O}_{3}=0.63, \mathrm{MgO}=0.82, \mathrm{FeO}$ $=0.09, \mathrm{TiO}_{2}=0.069, \mathrm{P}_{2} \mathrm{O}_{5}=0.001, \mathrm{MnO}=0.01, \mathrm{H}_{2} \mathrm{O}=$ 8.16 , and loss of ignition $(\mathrm{LOI})=16.59 . \mathrm{Z}$ was applied to the near-surface soil as basal fertilizer with $\mathrm{N}$. Based on the traditional fertilization method in the experimental station, $\mathrm{N}\left(157.5 \mathrm{~kg} \mathrm{ha}^{-1}\right)$ as urea was applied to the near-surface soil layer in three parts: $60 \%$ - basal, $30 \%$ - 10 days after transplanting and $10 \%-15$ days after the jointing-booting stage, respectively. $\mathrm{K}\left(\mathrm{K}_{2} \mathrm{O}, 72 \mathrm{~kg} \mathrm{ha}^{-1}\right)$ was applied in the form of potassium sulfate in two fractions: $50 \%$ basal and 50\% 15 days after the jointing-booting stage, respectively for all 4 treatments. $\mathrm{P}\left(\mathrm{P}_{2} \mathrm{O}_{5}, 172 \mathrm{~kg} \mathrm{ha}^{-1}\right)$ was applied as the basal fertilizer. The traditional variety used in the experimental station was Gangyu6 (Japonica rice) for both experiments over two years. Sowing begins on the 22nd of April, with transplanting being conducted on the 28th of May. The seeding recovery stage (R) begins on the 29th of May, the tillering stage $(\mathrm{T})$ on the 5th of June, the jointing-booting stage (J) occurs on 4-6th of July, the heading-flowering stage $(\mathrm{H})$ on $3 \mathrm{rd}-7$ th of August, the milky ripening stage (M) on 23rd-28th of August, the yellow ripening stage $(\mathrm{Y})$ on 5-10th of September and rice harvest on 16-20th of September, respectively. Each hill had 3 rice seedlings $(7 \times 17$-hills per plot). Plot sizes were $2.5 \times 2 \mathrm{~m}^{2}$ and rice was transplanted at $14 \times 30 \mathrm{~cm}$ spacing. The plots were regularly hand-weeded and pesticides were used to prevent insect and pest damage. No noticeable crop damage was observed during the experiment. The water layer in these plots was maintained at $1-7 \mathrm{~cm}$ in rice whole growth stages. Water was distributed by pipe to each plot for irrigation. Water depth was measured at a permanently fixed depth gauge. The irrigation water flow was stopped 15 days before harvest.

Crop samples for biomass, $\mathrm{N}$ accumulation and leaf area index (LAI) were taken 4-5 times from transplanting onward. The sampling days were on June the 6 th and 22nd 
at the tilling stage, July the 5 th and 12 th at the jointing-booting stage, August the 6th and 8th at the heading-flowering stage, August the 26th and September the 2nd at the milky ripening stage and September the 15th and 18th at the yellow ripening stage, respectively. At each sampling, 2 hills per plot with 3 replications were removed, separated and rinsed. The dry weight of the plant was determined after drying at $75^{\circ} \mathrm{C}$ until a constant weight was reached. LAI was determined using a Plant Canopy Analyser LICOR, model-2000. The root cap ratio refers to the ratio of the dry weight of the underground part of the plant to the aboveground part. For each plot, a 0.14 (width) $\times 0.3$ (length) $\times 0.3$ (active rooting depth) metre clod sample transferred into a mesh bag made from 100 mesh nylon mesh. After water panning, the roots were separated and the root morphology was determined. The roots were randomly selected at the milky-ripening stage to calculate the average main root length and root diameter using Vernier Calipers. The displacement method was used to accurately obtain the volume of the roots. The bleeding rate defined as the root activity was measured using cotton traps (Zhang et al., 2013). After the removal of the rice stem at around $10 \mathrm{~cm}$ above ground level, pre-weighted absorbent cotton was placed on the cut surface of the stump and wrapped in plastic film secured by a rubber band. Pre-weighed cotton was weighed again after $14 \mathrm{~h}$ from 6:00 p.m. till the next day 8:00 a.m. to calculate the bleeding rate.

At the end of the growth stage, the rice grain yield was calculated based on a $12-14 \%$ moisture content. The number of panicles was counted from three randomly selected plants and the weight of the grains per panicle was obtained using electronic scales. The unfilled grain percentage and 1000 -grain weight were determined after the process of drying and enzyme deactivation.

Soil samples from depths of $0-30 \mathrm{~cm}(15 \mathrm{~cm})$ were taken both in the vegetative period (15 days after transplanting) and reproductive period (5 days after the milky ripening stage). The soil samples remaining in the centrifuge tubes were extracted using $60 \mathrm{ml}$ of $1 \mathrm{M} \mathrm{NH}_{4} \mathrm{OAc}$ solution $(\mathrm{pH}$ 7.0) followed by steam distillation to determine the soil CEC (Rabai et al., 2013). The total N concentration in the plant and soil were determined by the semi-micro Kjeldahl method and available $\mathrm{K}$ was tested using a flame photometer for $\mathrm{K}$ available on the exchange sites of Z (Shi and Bao, 1996). Soil samples were passed through a $2 \mathrm{~mm}$ sieve after being blended, and air-dried in a laboratory and $5 \mathrm{~g}$ of each soil sample was extracted using $50 \mathrm{ml}$ of $2 \mathrm{M} \mathrm{KCl}$ solution. Concentrations of $\mathrm{NH}_{4}-\mathrm{N}$ and $\mathrm{NO}_{3}-\mathrm{N}$ were determined using the AA3 Continuous Flow Analytical System (Shi and Bao, 1996; Malekian et al., 2011).

All data (two-year mean) were subjected to analysis of variance (ANOVA) using SAS9.3 software. The separation of the means was performed using least significant difference (LSD).
RESULTS

Figures 1 and 2 show the different growth and development of rice within 4 treatments. Rice plots treated with $\mathrm{N}_{1} \mathrm{Z}_{10}, \mathrm{~N}_{3} \mathrm{Z}_{0}$ and $\mathrm{N}_{3} \mathrm{Z}_{10}$ produced higher LAI and biomass compared with $\mathrm{N}_{1} \mathrm{Z}_{0}$. The LAI and biomass of $\mathrm{N}_{1} \mathrm{Z}_{10}$ does not seem to differ significantly from those of $\mathrm{N}_{3} \mathrm{Z}_{0}$. In the rice reproductive period, $\mathrm{N}_{3} \mathrm{Z}_{0}$ and $\mathrm{N}_{3} \mathrm{Z}_{10}$ treatments produced better performances with regard to LAI and biomass whereas $\mathrm{N}_{1} \mathrm{Z}_{0}$ and $\mathrm{N}_{1} \mathrm{Z}_{10}$ exerted a more obvious influence at the initiation of the rice growth stage. Maximum LAI (3.67) and biomass $\left(13893.74 \mathrm{~kg} \mathrm{ha}^{-1}\right)$ were observed for $\mathrm{N}_{3} \mathrm{Z}_{10} \cdot \mathrm{N}_{3} \mathrm{Z}_{10}$ and $\mathrm{N}_{1} \mathrm{Z}_{10}$ treatments resulted in a 37.3 and $18.8 \%$ heavier biomass compared with $\mathrm{N}_{1} Z_{0}$. Compared with $\mathrm{N}_{3} \mathrm{Z}_{0}, \mathrm{~N}_{3} \mathrm{Z}_{10}$ and $\mathrm{N}_{1} \mathrm{Z}_{10}$ increased the biomass by 18.7 and $2.8 \%$, respectively.

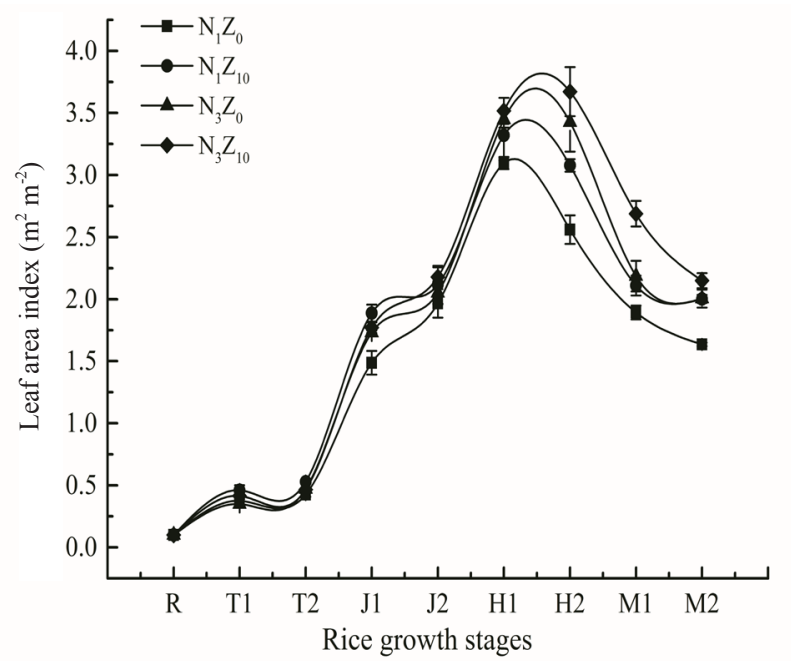

Fig. 1. Leaf area index changes at different rice growth stages. R, $\mathrm{T}, \mathrm{J}, \mathrm{H}$ and $\mathrm{M}$ were the stages of recovery stage, tillering stage, jointing-booting stage, heading-flowering stage and milky ripening stage, respectively.

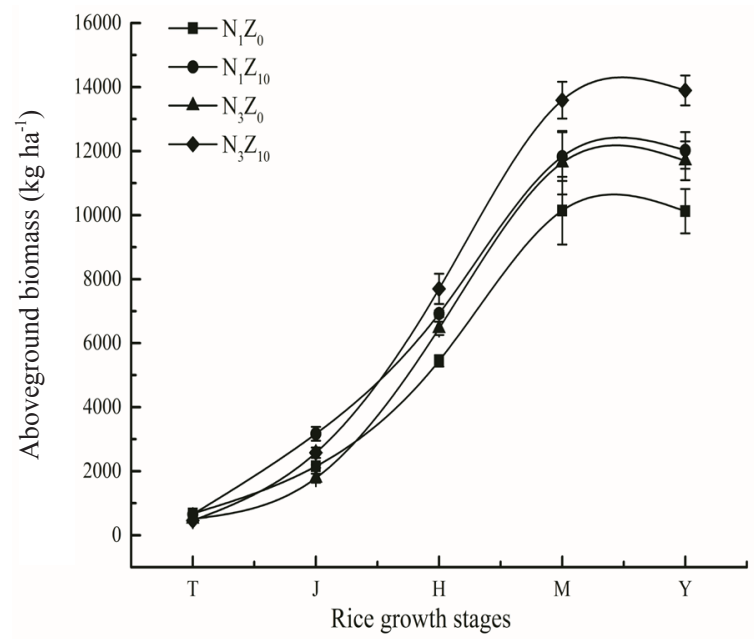

Fig. 2. Biomass changes at different rice growth stages. R, T, J, H, $\mathrm{M}$ and $\mathrm{Y}$ were the stages of recovery stage, tillering stage, jointing-booting stage, heading-flowering stage, milky ripening stage and yellow ripening stage, respectively. 
Table 2. Rice grain yield, yield components, soil residual nitrogen and soil cation exchange capacity as affected by zeolite and nitrogen application at rice harvest time: urea used as basal fertilization one time $\left(\mathrm{N}_{1} \mathrm{Z}_{0}\right), \mathrm{N}_{1} \mathrm{Z}_{0}$ with zeolite $\left(\mathrm{N}_{1} \mathrm{Z}_{10}\right)$, urea used as third-split fertilization $\left(\mathrm{N}_{3} \mathrm{Z}_{0}\right), \mathrm{N}_{3} \mathrm{Z}_{0}$ with zeolite $\left(\mathrm{N}_{3} \mathrm{Z}_{10}\right)$

\begin{tabular}{lccccc}
\hline Treatments & $\begin{array}{c}\text { Grain yield } \\
\left(\mathrm{t} \mathrm{ha}^{-1}\right)\end{array}$ & $\begin{array}{c}\text { 1000-grain weight } \\
(\mathrm{g})\end{array}$ & $\begin{array}{c}\text { Unfilled grain } \\
\text { percentage }(\%)\end{array}$ & $\begin{array}{c}\text { CEC } \\
\left(\mathrm{cmol} \mathrm{kg}^{-1}\right)\end{array}$ & $\begin{array}{c}\text { SRN } \\
\left(\mathrm{g} \mathrm{kg}^{-1}\right)\end{array}$ \\
\hline $\mathrm{N}_{1} \mathrm{Z}_{0}$ & $7.28 \mathrm{c}$ & $26.270 \mathrm{c}$ & $4.43 \mathrm{a}$ & $11.99 \mathrm{~b}$ & $0.46 \mathrm{a}$ \\
$\mathrm{N}_{1} \mathrm{Z}_{10}$ & $7.90 \mathrm{ab}$ & $26.648 \mathrm{~b}$ & $2.60 \mathrm{c}$ & $15.01 \mathrm{a}$ & $0.51 \mathrm{a}$ \\
$\mathrm{N}_{3} \mathrm{Z}_{0}$ & $7.74 \mathrm{~b}$ & $26.542 \mathrm{~b}$ & $4.34 \mathrm{ab}$ & $12.05 \mathrm{~b}$ & $0.47 \mathrm{a}$ \\
$\mathrm{N}_{3} \mathrm{Z}_{10}$ & $8.06 \mathrm{a}$ & $26.848 \mathrm{a}$ & $3.01 \mathrm{bc}$ & $13.69 \mathrm{a}$ & $0.49 \mathrm{a}$ \\
\hline
\end{tabular}

Mean values followed by different indices are significant at 0.05 probability level. CEC - soil exchange capacity, SRN - soil residual nitrogen content.

The effects of different combinations of $\mathrm{N}$ application frequencies with $\mathrm{Z}$ on rice grain yield and yield components are shown in Table 2 . Rice grain yield with $\mathrm{N}_{3} \mathrm{Z}_{10}$ and $\mathrm{N}_{1} \mathrm{Z}_{10}$ treatments were significantly enhanced by 8.5 and $10.7 \%$ compared with $\mathrm{N}_{1} \mathrm{Z}_{0}$. What's more, $\mathrm{N}_{3} \mathrm{Z}_{10}$ and $\mathrm{N}_{1} \mathrm{Z}_{10}$ treatments can also lead to higher 1000-grain weight and the lower unfilled grain percentage compared with $\mathrm{N}_{1} \mathrm{Z}_{0}$. It is suggested that the $\mathrm{Z}$ amendment could enhance rice grain yield mainly due to the higher 1000-grain weight and lower unfilled grain percentage. However, there is no clear difference between $\mathrm{N}_{1} \mathrm{Z}_{10}$ and $\mathrm{N}_{3} \mathrm{Z}_{0}$ on the 1000-grain weight of rice.

$\mathrm{N}$ accumulation at various growth stages of rice in both of the two growing seasons are shown in Fig. 3. Rice with $\mathrm{N}_{3} \mathrm{Z}_{0}$ and $\mathrm{N}_{3} \mathrm{Z}_{10}$ treatments achieved a higher $\mathrm{N}$ uptake compared with $\mathrm{N}_{1} \mathrm{Z}_{0}$ at harvest time, which is in complete contrast to the result from the tilling stage to the jointingbooting stage. This was due to the fact that the applied $\mathrm{N}$ was lower than that of $\mathrm{N}_{1} \mathrm{Z}_{0}$ and $\mathrm{N}_{1} \mathrm{Z}_{10}$ treatments at the initial growth stage. The maximum value of $\mathrm{N}$ uptake at harvest time $\left(81.61 \mathrm{~g} \mathrm{~kg}^{-1}\right)$ was observed in $\mathrm{N}_{3} \mathrm{Z}_{10}$. This

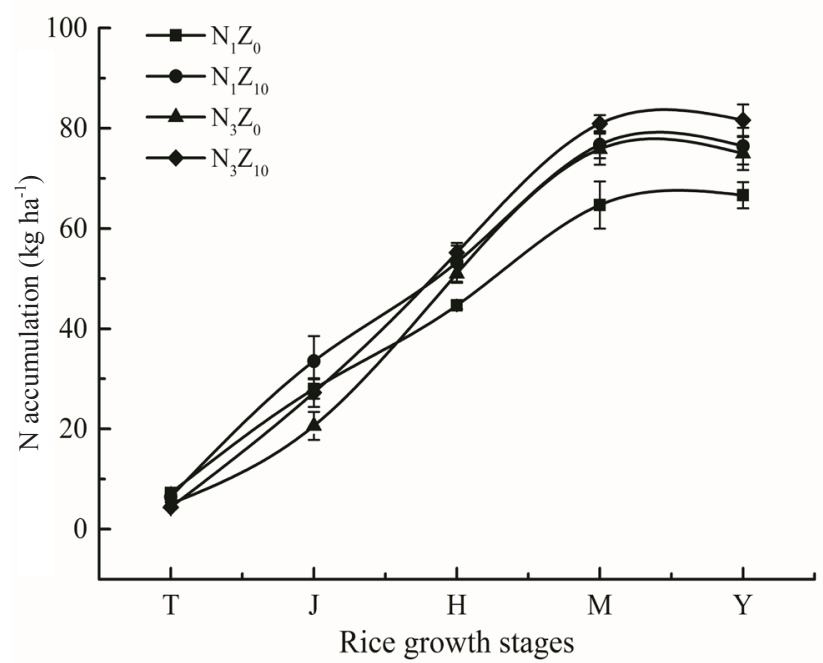

Fig. 3. $\mathrm{N}$ accumulation at different rice growth stages. R, T, J, H, $\mathrm{M}$ and $\mathrm{Y}$ were the stages of recovery stage, tillering stage, jointing-booting stage, heading-flowering stage, milky ripening stage and yellow ripening stage, respectively. result suggests that the $\mathrm{Z}$ amendment regulated the soil available $\mathrm{N}$ from the tillering stage to the jointing-booting stage. The dynamic changes in $\mathrm{N}$ matched the $\mathrm{N}$ requirement of the rice plant and finally $\mathrm{N}_{3} \mathrm{Z}_{10}$ produced a higher grain yield.

The impacts of different $\mathrm{N}$ management regimes on soil residual N (SRN) and CEC are shown in Table 2. Soil water and nutrition supply capacity has been shown to depend on CEC. There were no significant effects on soil CEC between different $\mathrm{N}$ application frequencies. Higher soil $\mathrm{CEC}$ was achieved at many $\mathrm{N}$ application frequencies with $\mathrm{Z}$ amendments. However, both $\mathrm{N}$ application frequencies and $Z$ had little effect on SRN. The average content of SRN was lower than its original content. This may be due to $\mathrm{N}$ losses in the saturated conditions of rice fields. Adequate $\mathrm{Z}$ application rates greatly contributed to the CEC and $\mathrm{Z}$ amendment that increased soil-available $\mathrm{N}$ retention might also exhibit the continuing effect of boosting soil fertility over the next year.

The reasons for the enhancement of dry weight biomass and $\mathrm{N}$ accumulation are explored in Table 3. During the vegetative period of rice, $\mathrm{N}_{1} \mathrm{Z}_{0}, \mathrm{~N}_{1} \mathrm{Z}_{10}$ and $\mathrm{N}_{3} \mathrm{Z}_{10}$ treatments achieved higher $\mathrm{NH}_{4}-\mathrm{N}$ content in soil compared with $\mathrm{N}_{3} \mathrm{Z}_{0} . \mathrm{NO}_{3}-\mathrm{N}$ content of $\mathrm{N}_{1} \mathrm{Z}_{0}$ treatment resulted in the lowest content of $\mathrm{NH}_{4}-\mathrm{N}$ due to long-term $\mathrm{N}$ consumption through leaching or uptake by plants under the one-time $\mathrm{N}$ application method. It demonstrates that $\mathrm{Z}$ addition to soil increased the $\mathrm{N}$ availability due to its longer controlled-release time of $\mathrm{NH}_{4}-\mathrm{N}$. However, during the rice reproductive period, there were no clear differences in available $\mathrm{N}$ between different treatments, which indicated that the controlled-release function of $\mathrm{Z}$ mainly happened at the initial growth stages of rice rather than in the reproductive period.

Regarding the chemical composition, $\mathrm{K}_{2} \mathrm{O}$ constitutes a significant portion of $Z$. In the vegetative period of rice, $\mathrm{N}_{1} \mathrm{Z}_{10}$ and $\mathrm{N}_{3} \mathrm{Z}_{10}$ treatments considerably increased the available $\mathrm{K}$ content of soil compared with $\mathrm{N}_{1} \mathrm{Z}_{0}$. The $\mathrm{K}$ content of $\mathrm{N}_{3} \mathrm{Z}_{0}$ was higher than that of $\mathrm{N}_{1} \mathrm{Z}_{0}$ mainly due to the fact that considerable amounts of $\mathrm{K}$ were utilized by rice plants under the one-time $\mathrm{N}$ application method. During the reproductive period, $Z_{10}$ treatment still significantly 
Table 3. $\mathrm{NH}_{4}-\mathrm{N}, \mathrm{NO}_{3}-\mathrm{N}$ and potassium content in soil as affected by zeolite and nitrogen management in different rice growth periods: urea used as basal fertilization one time $\left(\mathrm{N}_{1} \mathrm{Z}_{0}\right), \mathrm{N}_{1} \mathrm{Z}_{0}$ with zeolite $\left(\mathrm{N}_{1} \mathrm{Z}_{10}\right)$, urea used as third-split fertilization $\left(\mathrm{N}_{3} \mathrm{Z}_{0}\right), \mathrm{N}_{3} \mathrm{Z}_{0}$ with zeolite $\left(\mathrm{N}_{3} \mathrm{Z}_{10}\right)$

\begin{tabular}{|c|c|c|c|c|c|c|}
\hline \multirow{2}{*}{ Treatments } & \multicolumn{3}{|c|}{ In vegetative period $\left(\mathrm{mg} \mathrm{kg}^{-1}\right)$} & \multicolumn{3}{|c|}{ In reproductive period $\left(\mathrm{mg} \mathrm{kg}^{-1}\right)$} \\
\hline & $\mathrm{NH}_{4}-\mathrm{N}$ & $\mathrm{NO}_{3}-\mathrm{N}$ & $\mathrm{K}$ & $\mathrm{NH}_{4}-\mathrm{N}$ & $\mathrm{NO}_{3}-\mathrm{N}$ & $\mathrm{K}$ \\
\hline $\mathrm{N}_{1} \mathrm{Z}_{0}$ & $16.33 \mathrm{a}$ & $8.49 b$ & $274.54 \mathrm{c}$ & $0.948 \mathrm{a}$ & $0.841 \mathrm{a}$ & $25.50 \mathrm{c}$ \\
\hline $\mathrm{N}_{1} \mathrm{Z}_{10}$ & $17.44 \mathrm{a}$ & $10.59 \mathrm{ab}$ & $302.72 b$ & $0.952 \mathrm{a}$ & $0.842 \mathrm{a}$ & $28.50 \mathrm{~b}$ \\
\hline $\mathrm{N}_{3} \mathrm{Z}_{0}$ & $11.29 b$ & $10.71 \mathrm{ab}$ & $311.14 b$ & $0.986 \mathrm{a}$ & $0.873 \mathrm{a}$ & $24.00 \mathrm{c}$ \\
\hline $\mathrm{N}_{3} \mathrm{Z}_{10}$ & $15.70 \mathrm{a}$ & $12.81 \mathrm{a}$ & $353.68 \mathrm{a}$ & $1.012 \mathrm{a}$ & $0.863 \mathrm{a}$ & $30.99 a$ \\
\hline
\end{tabular}

Mean values followed by different indices are significant at 0.05 probability level.

Table 4. Root system as affected by zeolite and nitrogen managements at the milky-ripening stage: urea used as basal fertilization once $\left(\mathrm{N}_{1} \mathrm{Z}_{0}\right), \mathrm{N}_{1} \mathrm{Z}_{0}$ with zeolite $\left(\mathrm{N}_{1} \mathrm{Z}_{10}\right)$, urea used as third-split fertilization $\left(\mathrm{N}_{3} \mathrm{Z}_{0}\right), \mathrm{N}_{3} \mathrm{Z}_{0}$ with zeolite $\left(\mathrm{N}_{3} \mathrm{Z}_{10}\right)$, the root cap ratio refers to the ratio of the dry weight of the underground part to the aboveground part

\begin{tabular}{lcccccc}
\hline Treatments & $\begin{array}{c}\text { Dry weight } \\
\left(\text { g plant }^{-1}\right)\end{array}$ & $\begin{array}{c}\text { Root cap ratio } \\
(\%)\end{array}$ & $\begin{array}{c}\text { Main root length } \\
(\mathrm{cm})\end{array}$ & $\begin{array}{c}\text { Root diameter } \\
(\mathrm{mm})\end{array}$ & $\begin{array}{c}\text { Root volume } \\
\left(\mathrm{cm}^{3}\right)\end{array}$ & $\begin{array}{c}\text { Root activity } \\
\left(\mathrm{g} \mathrm{h}^{-1}\right)\end{array}$ \\
\hline $\mathrm{N}_{1} \mathrm{Z}_{0}$ & $6.38 \mathrm{c}$ & $7.61 \mathrm{a}$ & $30.81 \mathrm{~b}$ & $0.79 \mathrm{~b}$ & $33.45 \mathrm{~b}$ & $0.11 \mathrm{c}$ \\
$\mathrm{N}_{1} \mathrm{Z}_{10}$ & $7.56 \mathrm{a}$ & $9.11 \mathrm{a}$ & $35.60 \mathrm{a}$ & $0.98 \mathrm{a}$ & $38.48 \mathrm{a}$ & $0.13 \mathrm{~b}$ \\
$\mathrm{~N}_{3} \mathrm{Z}_{0}$ & $6.58 \mathrm{bc}$ & $8.53 \mathrm{a}$ & $34.35 \mathrm{a}$ & $0.91 \mathrm{ab}$ & $36.15 \mathrm{ab}$ & $0.13 \mathrm{~b}$ \\
$\mathrm{~N}_{3} \mathrm{Z}_{10}$ & $7.16 \mathrm{ab}$ & $9.59 \mathrm{a}$ & $37.75 \mathrm{a}$ & $0.97 \mathrm{ab}$ & $38.12 \mathrm{a}$ & $0.15 \mathrm{a}$ \\
\hline
\end{tabular}

Mean values followed by different indices are significant at 0.05 probability level.

increased soil $\mathrm{K}$ content compared with $\mathrm{Z}_{0}$. It appears that the $\mathrm{Z}$ amendment increased soil $\mathrm{K}$ content throughout the growth period of rice.

Table 4 shows the effects of various $\mathrm{N}$ management regimes on rice root morphology and activity. According to Table 4, the $\mathrm{Z}$ amendment significantly increased the root dry weight, main root length, diameter, root volume and root activity compared with $\mathrm{N}_{1} \mathrm{Z}_{0}$. Developed root traits may enhance the nutrient transport from the root to the aboveground parts and result in higher biomass and grain yield. However, $\mathrm{Z}$ input did not statistically significantly improve the root cap ratio.

\section{DISCUSSION}

$\mathrm{N}$ nutrition is one of the most pivotal factors of crop production. The mixture between $\mathrm{Z}$ and $\mathrm{N}$, which is comparable to slow-release fertilizers, played an important role in the rice grain yield increasing (Sepaskhah and Barzegar, 2010). Compared with $\mathrm{N}_{1} \mathrm{Z}_{0}$, the rice grain yield resulting from the $\mathrm{N}_{3} \mathrm{Z}_{10}$ and $\mathrm{N}_{1} \mathrm{Z}_{10}$ treatments were significantly enhanced by 8.5 and $10.7 \%$ mainly due to a higher 1000-grain weight and lower unfilled grain percentage. Similar results were found by Sepaskhah (Sepaskhah and Yousefi, 2007; Sepaskhah and Barzegar, 2010), but they found that the $\mathrm{Z}$ amendment could only slightly enhance the 1000-grain weight. However, there were no clear differences between $\mathrm{N}_{1} \mathrm{Z}_{10}$ and $\mathrm{N}_{3} \mathrm{Z}_{0}$ on 1000 -grain weight of rice. Some researchers have suggested that the higher 1000-grain weight was obtained mainly due to an enhancement in sink and source parameters (Wu et al., 2016a). In the present study, when compared with $\mathrm{N}_{3} \mathrm{Z}_{0}$, the sink parameter of the $\mathrm{N}_{1} \mathrm{Z}_{10}$ treatment was significantly enhanced by the one-time $\mathrm{N}$ application.

In our research, $\mathrm{N}_{3} \mathrm{Z}_{10}$ and $\mathrm{N}_{1} \mathrm{Z}_{10}$ treatments resulted in a 22.4 and $14.7 \%$ higher $N$ uptake than $N_{1} Z_{0}$. The difference between $\mathrm{N}_{1} \mathrm{Z}_{10}$ and $\mathrm{N}_{3} \mathrm{Z}_{0}$ was small at harvest time. The dominant reasons for the trend that $\mathrm{Z}$ clearly increased $\mathrm{N}$ uptake may be (1) $\mathrm{NH}_{4}^{+}$absorption by $\mathrm{Z}$ to decrease $\mathrm{N}$ losses when $\mathrm{N}$ is available at the initial growth stage of rice, and (2) slow release of $\mathrm{N}$ in contrast to $\mathrm{N}$ management without Z (Gholamhoseini et al., 2012; Malekian et al., 2011). A larger average content of available $\mathrm{N}$ released by $\mathrm{Z}$ that corresponded to the $\mathrm{N}$ requirement of the rice plant from the jointing-booting stage in surface soil resulted in a higher $\mathrm{N}$ uptake. In fact, when $\mathrm{N}$ was applied at early days of the plant life cycle, the $\mathrm{Z}$ amendment could decrease $\mathrm{N}$ availability to the plant due to its high CEC. Ippolito et al. (2011) showed that $\mathrm{N}$ with a $\mathrm{Z}$ amendment contained more $\mathrm{NH}_{4}-\mathrm{N}$ at day 7 and less $\mathrm{NH}_{4}-\mathrm{N}$ at day 35. It is demonstrated that at the first 7 days, $\mathrm{Z}$ decreased $\mathrm{N}$ availability to the plant and lead to slow growth. In this experiment, Fig. 3 showed an observable shrinkage in $\mathrm{N}$ uptake and biomass at the initial tillering stage with $\mathrm{Z}$ addition. However, it is apparent that $\mathrm{Z}$ clearly alleviated $\mathrm{N}$ stress from the tillering stage to jointing-booting stage. At the jointing-booting stage, $\mathrm{N}$ uptake of the $\mathrm{N}_{1} \mathrm{Z}_{10}$ and $\mathrm{N}_{3} \mathrm{Z}_{10}$ treatments were inclined to be higher than that of $\mathrm{N}_{1} \mathrm{Z}_{0}$ and $\mathrm{N}_{3} \mathrm{Z}_{0}$.

$\mathrm{N}_{1} \mathrm{Z}_{10}$ and $\mathrm{N}_{3} \mathrm{Z}_{10}$ treatments resulted in a higher $\mathrm{NH}_{4}-\mathrm{N}$ content in soil compared with $\mathrm{N}_{3} \mathrm{Z}_{0}$ at the rice tillering stage. However, there were no clear differences in the $\mathrm{N}$ 
available at harvest time, which indicated that the controlled-release function of $\mathrm{Z}$ mainly occurred at the initial growth stages of the rice plant rather than in the reproductive period of rice. The slow-release fertilizer allowed for the successive release rate of $\mathrm{N}$ to correspond well with the $\mathrm{N}$ requirements of crops (Wu et al., 2016b; Geng et al., 2015). Furthermore, the $Z$ amendment could also significantly increase the $\mathrm{N}$ availability for crops similarly to the effects of the slow-release fertilizer (Rehakova et al., 2004; Gholamhoseini et al., 2012).

Either in the vegetative period or reproductive period of rice, $Z_{10}$ resulted in a greater average $K$ concentration compared with $\mathrm{Z}_{0}$. $\mathrm{Z}$ improved the $\mathrm{N}$ use efficiency through increased $\mathrm{N}$ availability and reduced $\mathrm{N}$ losses through the leaching of exchange cations, especially $\mathrm{Na}^{+}$and $\mathrm{K}^{+}$ (Leggo, 2000; Harland et al., 1997; Mohammad et al., 2004). Ferguson et al. (1986) found that the establishment of creeping bentgrass decreased as the $\mathrm{Z}$ application rate increased by 5 to $10 \%$ (by volume), this phenomenon was associated with a decrease in $\mathrm{Z}$ sodium content. These results suggest that there could be abundant $\mathrm{K}$ and slight $\mathrm{Na}$ exchanged by $\mathrm{NH}_{4}{ }^{+}$from $\mathrm{Z}$ in the surface soil, which might greatly enhance rice growth. Moreover, there may be interaction effects between $\mathrm{K}$ and slow-release $\mathrm{N}$ to stimulate rice biomass and LAI. Furthermore, a higher total $\mathrm{P}$ and available $P$ in the soil with $Z$ treatment may also contribute to higher biomass and LAI to achieve a higher rate of rice production (Gholamhoseini et al., 2012). Natural Z incorporated into soil could improve the long-term soil quality by enhancing soil CEC. This affected the retention of the most essential nutrients for crops such as N, P and $\mathrm{K}$ in soil (Li et al., 2013). However, $\mathrm{Z}$ also provided some ions such as $\mathrm{Ca}^{2+}$ and $\mathrm{Mg}^{2+}$ (Doula et al., 2012). The increased content of $\mathrm{Ca}^{2+}$ and $\mathrm{Mg}^{2+}$ present in the soil with increasing $\mathrm{Z}$ application rates may affect soil structure and result in soil hardening. Therefore, appropriate rates of $Z$ are critical for rice farmers to increase rice grain yield.

The NUE is very low with an average of $27.5 \%$ in China, which has led to some concerns that excessive $\mathrm{N}$ in field negatively may influence the quality of the environment through leaching and volatilization (Malekian et al., 2011; Wu et al., 2016b). Rice roots, as important organs for absorbing water, nutrients, and growth regulation, have a direct influence on aboveground biomass and nutrient use. Root growth can be used to determine the uptake ability of nutrition and water, it also reflects crop growth and development. In our research, it was found that $\mathrm{Z}$ input could statistically significantly enhance the root system. There was little information available on the effects of $\mathrm{Z}$ on root morphology. However, the effects of slow-release fertilizer on root morphology were known while the effects of $\mathrm{N}$ application plus $\mathrm{Z}$ are comparable to the slow-release fertilizer of N. Slow-release fertilizer based on biochar can delay root senescence and greatly increase the main root length, volume, active absorption area and root activity, which results in a higher rice grain yield (Zhang et al.,
2013). Rice grain yield has a significantly positive correlation with root dry weight, total root length, total root surface area, root bleeding intensity and the root cap ratio. All of these traits could be enhanced by slow-release fertilizer application (Peng et al., 2013). In conclusion, the enhanced $\mathrm{N}$ uptake and rice grain yield by $\mathrm{Z}$ were not only attributed to higher available $\mathrm{N}$ and $\mathrm{K}$ content in the soil but they were also attributed to a developed root system.

\section{CONCLUSIONS}

The results herein indicated that:

1. Zeolite application could greatly enhance rice growth and development.

2. At the vegetative stage of the life cycle, a higher content of available nitrogen and potassium in soil could contribute to a higher rice grain yield.

3. Using urea as a basal fertilizer in conjunction with zeolite could significantly increase nutrient retention, whilst conserving the biodiversity of the environment of paddy fields, and this approach is recommended in order to improve rice grain yield and decrease fertilizer application frequencies.

Conflict of interest: No conflict of interest exists in the submission of this manuscript.

\section{REFERENCES}

Barea J.M., 2015. Future challenges and perspectives for applying microbial biotechnology in sustainable agriculture based on a better understanding of plant-microbiome interactions. J. Soil Sci. Plant Nut., 15(2), 261-282. https://doi.org/10.4067/s0718-95162015005000021

Belder P., Bouman B.A.M., Cabangon R., Lu G., Quilang E.J.P., Li Y., and Tuong T.P., 2004. Effect of water-saving irrigation on rice yield and water use in typical lowland conditions in Asia. Agric. Water Manage., 65(3), 193-210. https://doi.org/10.1016/j.agwat.2003.09.002

Bi L., Zhang B., Liu G., Li Z., Liu Y., Ye C., and Linag Y., 2009. Long-term effects of organic amendments on the rice yields for double rice cropping systems in subtropical China. Agric Ecosyst Environ, 129(4), 534-541. https://doi.org/10.1016/j.agee.2008.11.007

Chen T., Wu Q., Zheng J., Xu X., Chi D., and Sun D., 2014. Effect of water and nitrogen coupling on rice yield based on clinoptilolite (in Chinese). J. Irri. and Drain, 4/5(33), 71-76.

Doula M.K., Elaiopoulos K., Kavvadias V.A., and Mavraganis V., 2012. Use of clinoptilolite to improve and protect soil quality from the disposal of olive oil mills wastes. J. Hazard. Mater, 207, 103-110. https://doi.org/10.1016/j.jhazmat.2011.04.014

Ferguson G.A., Peppe I.L., and Kneebone W.R., 1986. Growth of creeping bentgrass on a new medium for turfgrass growth: Clinoptilolite zeolite-amended sand. Agron. J., 78(6), 1095-1098.

https://doi.org/10.2134/agronj1986.00021962007800060031x

Geng J., Sun Y., Zhang M., Li C., Yang Y., Liu Z., and Li L., 2015. Long-term effects of controlled release urea application on crop yields and soil fertility under rice-oilseed rape rotation system. Field Crop Res., 184, 65-73.

https://doi.org/10.1016/j.fcr.2015.09.003 
Gholamhoseini M., AghaAlikhani M., Dolatabadian A., Khodaei-Joghan A., and Zakikhani H., 2012. Decreasing nitrogen leaching and increasing canola forage yield in a sandy soil by application of natural zeolite. Agron J, 104(5), 1467. https://doi.org/10.2134/agronj2012.0145

Gholamhoseini M., Ghalavand A., Khodaei-Joghan A., Dolatabadian A., Zakikhani H., and Farmanbar E., 2013. Zeolite-amended cattle manure effects on sunflower yield, seed quality, water use efficiency and nutrient leaching. Soil Till. Res., 126, 193-202. https://doi.org/10.1016/j.still.2012.08.002

Harland J., Lane S., and Price D., 1997. Further experiences with recycled zeolite as a substrate for the sweet pepper crop. Int. Symp. Grow Med. Soilless Culture, 481, 187-196. https://doi.org/10.17660/actahortic.1999.481.19

Ippolito J.A., Tarkalson D.D., and Lehrsch G.A., 2011. Zeolite soil application method affects inorganic nitrogen, moisture, and corn growth. Soil Sci., 176(3), 136-142. https://doi.org/10.1097/ss.0b013e31820e4063

Kavoosi M., 2007. Effects of zeolite application on rice yield, nitrogen recovery, and nitrogen use efficiency. Commun. Soil Sci. Plant Anal., 38(1-2), 69-76. https://doi.org/10.1080/00103620601093652

Leggo P.J., 2000. An investigation of plant growth in an organozeolitic substrate and its ecological significance. Plant Soil, 219, 135-146.

Li J., Wee C., and Sohn B., 2013. Effect of Ammonium- and Potassium-Loaded Zeolite on Kale, Growth and Soil Property. Amer. J. Plant Sci., 4(10), 1976-1982. https://doi.org/10.4236/ajps.2013.410245

Liu X., and Zhang C., 2005. Food security situation thinking and related measures in current China (in Chinese). Economy in Shandong, 20(6), 25-27.

Malekian R., Abedi-Koupai J., and Eslamian S.S., 2011. Influences of clinoptilolite and surfactant-modified clinoptilolite zeolite on nitrate leaching and plant growth. J. Hazard. Mater, 185(2-3), 970-976. https://doi.org/10.1016/j.jhazmat.2010.09.114

Mohammad M.J., Karam N.S., and Al-lataifeh N.K., 2004. Response of croton grown in zeolite-containing substrate to different concentrations of fertilizer solution. Commun. Soil Sci. Plant Anal., 35(15-16), 2283-2297. https://doi.org/10.1081/css-200030637

Peng Y., Ma J., Jiang M., Yan F., Sun Y., and Yang Z., 2013. Effects of slow/controlled release fertilizers on root morphological and physiological characteristics of rice (in Chinese). J. Plant Nut. Fert., 19(5), 1048-1057.
Rabai K.A., Ahmed O.H., and Kasim S., 2013. Use of formulated nitrogen, phosphorus, and potassium compound fertilizer using clinoptilolite zeolite in maize (Zea mays L.) cultivation. Emir. J. Food Agric., 25(9), 713-722. https://doi.org/10.9755/ejfa.v25i9.16248

Rehakova M., Čuvanová S., Dzivak M., Rimár J., and Gaval'Ova Z., 2004. Agricultural and agrochemical uses of natural zeolite of the clinoptilolite type. Curr. Opin. Solid State Mater Sci., 8(6), 397-404.

https://doi.org/10.1016/j.cossms.2005.04.004

Sandhu S.S., Mahal S.S, Vashist K.K., Buttar G.S., Brar A.S., and Singh M., 2012. Crop and water productivity of bed transplanted rice as influenced by various levels of nitrogen and irrigation in northwest India. Agric. Water Manag., 104, 32-39. https://doi.org/10.1016/j.agwat.2011.11.012

Sepaskhah A.R., and Barzegar M., 2010. Yield, water and nitrogen-use response of rice to zeolite and nitrogen fertilization in a semi-arid environment. Agric. Water Manag., 98(1), 38-44. https://doi.org/10.1016/j.agwat.2010.07.013

Sepaskhah A.R., and Yousefi F., 2007. Effects of zeolite application on nitrate and ammonium retention of a loamy soil under saturated conditions. Soil Res, 45(5), 368-373. https://doi.org/10.1071/sr06069

Shi R., and Bao S., 1996. Soil Agro-chemistrical Analysis. Beijing Agricultural Press, Beijing, P.R. China.

Weatherley L.R. and Miladinovic N.D., 2004. Comparison of the ion exchange uptake of ammonium ion onto New Zealand clinoptilolite and mordenite. Water Res., 38(20), 4305-4312. https://doi.org/10.1016/j.watres.2004.08.026

Wienhold B.J., Trooien T.P., and Reichman G.A., 1995. Yield and nitrogen use efficiency of irrigated corn in the northern great plains. Agron. J., 87, 842-846. https://doi.org/10.2134/agronj1995.00021962008700050010x

Wu Q., Xia G., Chen T., Chi D., Jin Y., and Sun D., 2016a. Impacts of nitrogen and zeolite managements on yield and physicochemical properties of rice grain. Int. J. Agric. Biol. Eng., 9(5): 93-100.

Wu Q., Xia G., Chen T., Wang X., Chi D., and Sun D., 2016 b. Nitrogen use and rice yield formation response to zeolite and nitrogen coupling effects: Enhancement in nitrogen use efficiency. J. Soil Sci. Plant Nut., 16(4), 999-1009. https://doi.org/10.4067/s0718-95162016005000073

Zhang W., Meng J., Wang J., Fan S., and Chen W., 2013. Effect of biochar on root morphological and physiological characteristics and yield in rice (in Chinese). Acta Agron. Sin., 39(8), 1445-1451. https://doi.org/10.3724/sp.j.1006.2013.01445 